\section{RELIABLE PPE ALL IN ONE PLACE}

To make sure you have the right, high-quality PPE in stock to protect you, your staff and your patients, 3M Oral Care is here to help.

A brand-new website dedicated to all things PPE was recently launched to make it even easier for you to find the products that you need. Simple to navigate, with a wealth of useful information to help you make the best decisions for you and your practice,

find all of the below and more at 3M.co.uk/dental-ppe:

- 3M Aura Particulate Health Respirator FFP2, Type IIR 1862+

- 3M Aura Disposable Health Respirator FFP3, Type IIR, 1863+

- Surgical Mask 1826

- Splash Resistant Surgical Mask $1820 \mathrm{~S}$

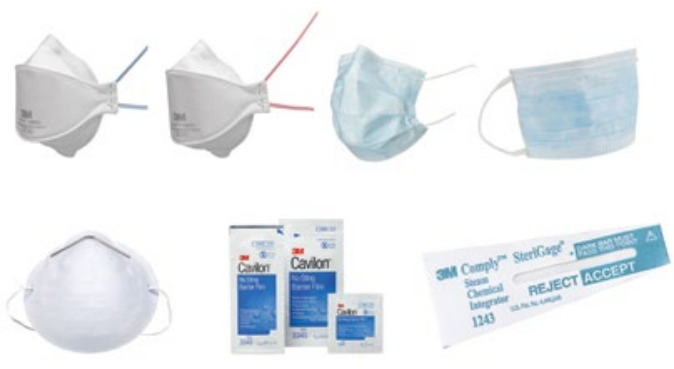

- 3M Triple Layer Molded face
Mask 2042F

- 3M Cavilon No Sting Barrier Film

- 3M Comply SteriGage Integrating Indicator.

For more information, call 08705360 036 or visit www.3M.co.uk/Dental. $3 \mathrm{M}$ is a trademark of the $3 \mathrm{M}$ Company.

\title{
A SUPERIOR LEVEL OF PROTECTION
}

If you are looking for reliable solutions that deliver a superior level of protection for you and your patients, you can have complete confidence in Nuview.

The range of solutions available to boost infection control and prevention protocols include:

- The JADE air purification system using Surgically Clean Air's state-of-the-art, multi-stage air purifying technologies to effectively and quietly clean and purify indoor air for hourly air changes

- The Uvex visor for comfortable personal protection with unmatched optical quality

- Zeiss Microscope drapes, which include the VisionGuard lens protection system.
For total protection, trust in Nuview.

For more information please call Nuview on 01453 872266, email info@nuview-ltd. com, visit www.nuview.co or 'like' Nuview on Facebook.

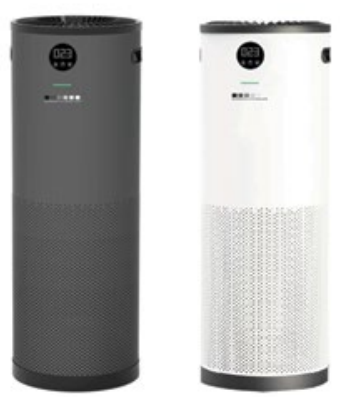

\section{A SHIELD THAT CAPTURES AEROSOLS DURING DRILLING AND SCALING}

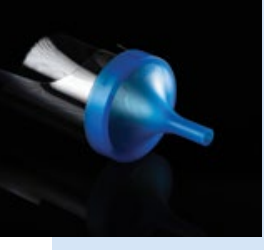

Splashes and aerosols produced by dental instruments harbour potentially dangerous pathogens. Studies show that viruses trapped within these aerosols can travel up to 20 feet from an infected person before settling on operatory surfaces and lingering in the air for hours.

CareShield is a shield that captures aerosols created during procedures such as drilling or ultrasonic scaling. Developed by Orsing, a division of Directa Dental
Group, the system consists of a cone-shaped, autoclavable connector that attaches to a disposable clear shield, which is changed between each patient. The CareShield system connects to the dental delivery unit for high-volume suction. It can be used in conjunction with Hygoformic, a mouldable saliva ejector that adjusts its shape and size to fit each patient. Hygoformic can be used with either low- or high volume suction and is designed using a bioplastic material made from sugarcane making it a very eco-friendly solution.Contact orsing@orsing.se.

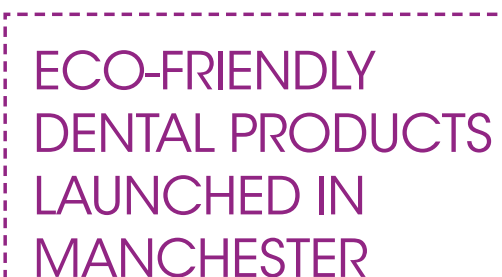

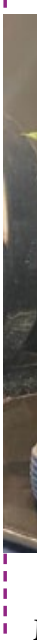

Manchester-based Portman dentist Daniel Sutcliffe and his family have launched their own eco-friendly bamboo toothbrush, dental floss in recyclable packaging and 'Earth Straw' in a bid to reduce the quantity of plastic dental products purchased and used in the UK.

The Sutcliffe Toothbrush Company's Bamboo Toothbrush was designed to be eco-friendly but also stylish and complementary to any bathroom décor. With a high quality beeswax finish, the toothbrush has a biodegradable bamboo handle, high quality Dupont nylon bristles, is BPA free, ethically sourced and recyclable: it comes in a cardboard outer box and a hygienic internal 'Eco-Wrap. The bamboo toothbrush is available in three different colours so that each member of the household can identify their own brush.

Hundreds of millions of plastic dental floss containers are thrown away every year. The Sutcliffe Toothbrush Company's Mint Dental Floss $(50 \mathrm{~m}$ ) comes in a biodegradable, recyclable box that is also the floss dispenser.

Although not specifically a dental product, the Earth Straw may help the public to reduce sugary/acidic contact with their teeth, but without creating single-use plastic waste. The Earth Straw is made from high quality, biodegradable bamboo that is reusable and easy to clean by hand or in the dishwasher. They come in a handy, washable bag with a slender cleaning brush.

The Sutcliffe Toothbrush Company's products are now available through Amazon. Find out more at http:// thesutcliffetoothbrushcompany.co.uk/. 